\title{
PENGARUH ALOKASI DANA DESA ( ADD ) TERHADAP \\ KESEJAHTERAAN MASYARAKAT DESA AIR HANGAT \\ KECAMATAN AIR HANGAT TIMUR \\ KABUPATEN KERINCI
}

\author{
Nanik Mandasari, S.IP, M.Si \\ Dosen Sekolah Tinggi Ilmu Administrasi Nusantara Sakti (STIA_NUSA) \\ Sungai Penuh-Kerinci
}

www.mandasarinanik.gmail.com

\begin{abstract}
ABSTRAK
Alokasi Dana Desa (ADD) merupakan wujud dari pemenuhan hak Desa untuk menyelenggarakan Otonomi Desa agar tumbuh dan berkembang mengikuti pertumbuhan dari Desa itu sendiri berdasarkan keanekaragaman, partisipasipatif, otonomi asli, demokratisasi dan pemberdayaan mayarakat. Salah satu alasan rasional mengapa perlu ada Alokasi Dana Desa (ADD) adalah Kebijakan ADD sejalan dengan agenda Otonomi daerah, dimana desa ditempatkan sebagai basis desentralisasi. Kebijakan ADD sangat relevan dengan perspektif yang menempatkan desa sebagai basis partisipasi. Rumusan masalah dalam penelitian ini adalah apakah terdapat pengaruh ADD terhadap Kesejahteraan Masyarakat Desa Air Hangat Kecamatan Air Hangat Timur Kabupaten Kerinci dan seberapa besar pengaruhnya. Penelitian ini dilakukan di Air Hangat Kecamatan Air Hangat Timur Kabupaten Kerinci. Populasi dalam penelitian ini sebanyak 312 KK dan Sampel yang digunakan sebanyak $31 \mathrm{KK}$. Penelitian ini merupakan penelitian kuantitatif yaitu penelitian yang menggunakan angka mulai dari pengumpulan data, penafsiran terhadap data tersebut serta penampilan dari hasilnya. Adapun hasil-hasil penelitian ini adalah Terdapat Pengaruh Positif yang Signifikan antara Alokasi Dana Desa terhadap Kesejahteraan Masyarakat Desa Air Hangat Kecamatan Air Hangat Timur Kabupaten Kerinci. Pengaruh Alokasi dana Desa (ADD) terhadap Kesejahteraan Masyarakat adalah sebesar $15,3 \%$. Adapun saran yang diberikan penulis pada pemerintah Desa Air Hangat adalah hendaknya pemerintah Desa Air Hangat lebih memperhatikan tentang pembinaan, pengawasan, dan evaluasi terhadap pelaksanaan ADD agar pelaksanaan ADD lebih tepat sasaran, serta hendaknya pemerintah Desa Air Hangat juga lebih memperhatikan tingkat pendidikan dan layanan kesehatan yang diperoleh masyarakat sehingga baik pendidikan maupun layanan kesehatan dapat diakses dengan mudah oleh seluruh lapisan masyarakat.
\end{abstract}

Kata Kunci : Alokasi Dana Desa dan Kesejahteraan Masyarakat

\section{ABSTRACK}

Village funds allocation is a form of village right fulfillment to organize village autonomy in order to grow and develope to follow the village growth it self base on the diversity, partipatory, pure autonomy, democracy and empowerment of society. One of reasons why the village funds allocation (ADD) was needed and ADD wisedom in same line with regional autonomy note when the village placed as base 
of decentralize ADD wisedom realy relevant with perspective that placed the village as base of participation. formulation problem in this research is there any influences ADD to the society welfare in Air Hangat village at Air Hangat Timur district Kerinci regency and how far the influences, this research had done in air hangat timur kerinci regency. The population in this research were $312 \mathrm{KK}$ and samples used $31 \mathrm{KK}$. This a quantitative research which used the numbering during the data collection, data 46overnment4646on, and data presentation. The result of this research were there positive significant influences between village funds allocation to the society welfare of Air Hangat village Air Hangat Timur district Kerinci regency. The influences of village funds allocation (ADD) to the society welfare was $15,3 \%$. As writer suggestion to the village 46overnment Air Hangat to more attention about 46overnment 46 activities of monitoring and 46overnment to the $A D D$ implementation in order to the $A D D$ right targeted, then the village 46overnment Air Hangat also more attention of educational degrees and health services of society in order to the education or healt services will accessed easily by whole society elements.

Key words : Village Funds Allocation and Society Welfare

\section{PENDAHULUAN}

Berdasarkan Peraturan Daerah Kabupaten Kerinci Nomor 5 Tahun 2007 tentang Alokasi Dana Desa pasal 8 dijelaskan bahwa rincian pengguanaan ADD adalah 30\% digunakan untuk dana operasional Pemerintahan Desa dan BPD. Sedangkan $70 \%$ untuk pelaksanaan pembangunan pada skala Desa dan kegiatan pemberdayaan masyarakat sesuai dengan daftar skala prioritas pembangunan Desa, baik fisik, ekonomi, sosial budaya sebagai dana stimulan. Alokasi Dana Desa untuk Desa Air Hangat Kecamatan Air Hangat Timur Kabupaten Kerinci tahun 2017 adalah sebesar Rp. 221.741.000,00.

Berdasarkan Peraturan Bupati Kerinci Nomor 2 Tahun 2017 tentang Tata Cara Pengalokasian, Peyaluran, Penggunaan Alokasi Dana Desa, Bagi Hasil Pajak dan Retribusi Daerah pasal 10 ayat 3, bahwa penggunaan ADD dan bagi hasil pajak dan retribusi daerah dalam APBDesa dialokasikan untuk penghasilan tetap Kepala Desa dan Perangkat Desa, penyelenggaraan Pemerintahan Desa, pembinaan kemasyarakatan dan pemberdayaan masyarakat.

Dari rincian penggunaan Alokasi Dana Desa tersebut, perlu adanya pengelolaan yang baik dari pemerintah desa agar dalam pelaksanaannya dapat sesuai dengan tujuan dan sasaran dari program Alokasi Dana Desa itu sendiri. Pengelola Alokasi Dana Desa Di Desa Air Hangat yag terdiri dari Kepala Desa, Pelaksana Teknis Pengelolaan Keuangan Desa (PTPKD), dan Bendahara Desa diharapkan mengerti dan paham dalam pengelolaan Alokasi Dana Desa.

Desa Air Hangat merupakan salah satu Desa dari 25 Desa yang ada di Kecamatan Air Hangat Timur Kabupaten Kerinci yang dalam penyelenggaraan pemerintahannya terutama dalam pengelolaan Alokasi Dana Desa masih perlu dievaluasi kembali sehingga dapat dijadikan pedoman dalam meningkatkan kesejahteraan masyarakat. Setelah melakukan pengamatan awal, kemudian ditemukan suatu permasalahan yang sangat penting dan menyangkut masalah 
pengelolaan Alokasi Dana Desa di Desa Air Hangat kecamatan Air Hangat Timur Kabupaten Kerinci, terdapat gejala-gejala tidak berkurangnya jumlah penduduk miskin, masih kurangnya sumber daya manusia yang dimiliki oleh pemerintah desa dalam mengelola keuangan desa, kurang berkembangnya usaha peningkatan pendapatan seperti pertanian, perdagangan dan lain sebagainya, kurang berkembangnya kelompok usaha di desa seperti kelompok tani, kelompok usaha bersama dan kelompok koperasi, dan kurangnya peningkatan pendapatan masyarakat.

Tujuan penelitian ini mengetahui pengaruh pengelolaan alokasi dana desa (ADD) terhadap kesejahteraan masyarakat desa di Desa Air Hangat kecamatan Air Hangat Timur Kabupaten Kerinci.

\section{Tinjauan Pustaka}

\subsection{Desa}

Menurut Undang-undang Nomor 6 Tahun 2014 Tentang Desa pasal 1 ayat 1 disebutkan bahwa "Desa adalah kesatuan masyarakat hukum yang memiliki batas wilayah yang berwenang untuk mengatur dan mengurus urusan pemerintahan , kepentingan masyarakat berdasarkan prakarsa masyarakat, hak asal-usul, dan/hak tradisional yang diakui dan dihormati dalam sistem pemerintahan Negara Kesatuan Republik Indonesia".

\section{A. Keuangan Desa}

Menurut Undang-undang Nomor 6 Tahun 2014 Tentang Desa pasal 71 ayat 1, disebutkan bahwa "keuangan desa adalah semua hak dan kewajiban desa yang dapat dinilai dengan uang serta segala sesuatu yang berupa uang dan barang yang berhubungan dengan pelaksanaan hak dan kewajiban desa". Keuangan desa yang berupa uang maupun barang kemudian dikelola oleh Kepala Desa yang melimpahkan sebagian kewenangannya kepada perangkat Desa yang ditunjuk untuk mengelola Keuangan Desa.

\section{B. Pendapatan Desa}

Menurut Undang-undang Nomor 6 Tahun 2014 Tentang Desa pasal 72 ayat 1, pendapatan Desa bersumber dari :

a. Pendapatan Asli Desa terdiri atas hasil usaha, hasil aset, swadaya dan patisipasi, gotong royong dan lain-lain pendapatan asli Desa,

b. Alokasi Anggaran Pendapatan dan Belanja Negara,

c. Bagian dari hasil pajak dan retribusi daerah Kabupaten/Kota,

d. Alokasi dana Desa yang merupakan bagian dari dana perimbangan yang diterima Kabupaten/Kota,

e. Bantuan keuangan dari Anggaran Pendapatan dan Belanja Daerah Provinsi dan Anggaran Pendapatan dan Belanja Daerah Kabupaten/Kota,

f. Hibah dan sumbangan yang tidak mengikat dari pihak ketiga, dan

g. Lain-lain pendapatan Desa yang sah.

\section{Belanja Desa}

Menurut Undang-undang Nomor 6 Tahun 2014 tentang Desa pasal 74 ayat 1, belanja Desa diprioritaskan untuk memenuhi kebutuhan pembangunan yang disepakati dalam Musyawarah Desa dan sesuai dengan prioritas Pemerintah Daerah Kabupaten/Kota, Pemerintah Daerah Provinsi dan Pemerintah. Kebutuhan pembangunan tersebut meliputi, tetapi tidak terbatas pada kebutuhan primer, 
pelayanan dasar, lingkungan dan kegiatan pemberdayaan masyarakat Desa. Yang dimaksud dengan tidak terbatas adalah kebutuhan pembangunan diluar pelayanan dasar yang dibutuhkan masyarakat Desa.

\subsection{Pengertian Alokasi Dana Desa (ADD)}

Berdasarkan Peraturan Bupati Kerinci Nomor 2 Tahun 2017 tentang Tata Cara Pengalokasian, Penyaluran, Penggunaan Alokasi Dana Desa, Bagi Hasil Pajak dan Retribusi Daerah pasal 1 ayat 11 dijelaskan bahwa yang dimaksud dengan "Alokasi Dana Desa adalah dana perimbangan yang diterima Kabupaten/Kota dalam Anggaran Pendapatan dan Belanja Daerah Kabupaten/Kota setelah dikurangi Dana Alokasi Khusus".

\section{A. Tujuan Alokasi dana Desa (ADD)}

Menurut Peraturan Daerah Kabupaten Kerinci Nomor 5 Tahun 2007 tentang Alokasi Dana Desa pasal 2, dijelaskan bahwa tujuan diberikannya alokasi dana desa adalah sebagai berikut :

a. Meningkatkan penyelenggaraan pemerintahan desa alam melaksanakan pelayanan pemerintahan, pemangunan dan kemasyarakatan sesuai kewenangan.

b. Meningkatkan kemampuan lembaga kemasyarakatan desa dalam perencanaan, pelaksanaan, dan pengendalian pembangunan secara partisipatif sesuai dengan potensi desa.

c. Meningkatkan pemerataan pendapatan, kesempatan bekerja dan kesempatan berusaha bagi masyarakat desa.

d. Mendorong swadaya gotong royong masyarakat.

\section{B. Arah Penggunaan Alokasi Dana Desa (ADD)}

Menurut Peraturan Bupati Kerinci Nomor 2 Tahun 2017 tentang Tata Cara Pengalokasian, Penyaluran, Penggunaan Alokasi Dana Desa, Bagi Hasil Pajak dan Retribusi Daerah pasal 10 ayat 3, disebutkan bahwa "penggunaan Alokasi Dana Desa dan Bagi Hasil Pajak dan Retribusi Daerah dalam APBDesa dialokasikan untuk penghasilan tetap Kepala Desa dan Perangkat Desa, penyelenggaraan Pemerintahan Desa, dan pembinaan kemasyarakatan dan pemberdayaan masyarakat".

\section{Pengawasan Alokasi Dana Desa (ADD)}

Menurut Peraturan Bupati Kerinci Nomor 2 Tahun 2017 tentang Tata Cara Pengalokasian, Penyaluran, Penggunaan Alokasi Dana Desa, Bagi Hasil Pajak dan Retribusi Daerah pasal 30, dijelaskan bahwa semua pihak berhak melakukan pengawasan terhadap pelaksanaan Alokasi Dana Desa dan Bagi Hasil Pajak dan Retribusi Daerah sehingga pelaksanaan Alokasi Dana Desa berjalan sesuai dengan tujuan dan sasaran Alokasi Dana Desa, pengawasan terhadap pelaksanaan Alokasi Dana Desa

\section{Indikator Alokasi Dana Desa (ADD)}

Menurut Peraturan Bupati Kerinci Nomor 2 Tahun 2017 Tentang Tata Cara Pengalokasian, Penyaluran dan Penggunaan Alokasi Dana Desa, Bagi Hasil Pajak dan Retribusi Daerah pasal 2 ayat 2, dengan adanya pengaturan Tata Cara Pengalokasian ini dapat dijadikan sebagai acuan bagi Pemerintah Kecamatan dan Kabupaten dalam penyaluran dan pelaksanaan penggunaan Alokasi Dana Desa.

\subsection{Pengertian Kesejahteraan}


Istilah kesejahteraan berasal dari kata sejahtera yang berarti aman, sentosa, dan makmur dan dapat berarti selamat dari gangguan. Sedangkan kesejahteraan diartikan dengan hal atau keadaan sejahtera, keamanan, keselamatan dan ketenteraman. Dengan kata lain sejahtera adalah keadaan dimana seseorang berada dalam kondisi yang aman, makmur, sentosa, serta selalu berada dalam keselamatan dan ketenteraman serta bebas dari gangguan.

Menurut Rambe dalam Rosni (2017:57) disebutkan bahwa "kesejahteraan adalah suatu tata kehidupan dan penghidupan sosial, material, maupun spiritual yang diliputi rasa keselamatan kesusilaan dan ketenteraman lahir batin yang memungkinkan setiap warga Negara untuk mengadakan usaha-usaha pemenuhan kebutuhan jasmani, rohani dan sosial yang sebaik-baiknya bagi diri, rumah tangga serta masyarakat dalam melanjutkan kehidupannya.

Berdasarkan pendapat diatas dapat ditarik kesimpulan bahwa kesejahteraan adalah suatu kondisi atau keadaan sejahtera dimana seseorang berada dalam kondisi aman, makmur dan sentosa serta dapat memenuhi kebutuhan pokok, jasmani, rohani dan sosial serta bebas dari ketakutan, gangguan kekhawatiran sehingga kehidupan seseorang berada dalam keadaan yang aman dan tentram baik lahir maupun batin.

\subsubsection{Indikator Kesejahteraan Masyarakat}

Menurut Badan Pusat Statistik (BPS) dalam Wulandari (2017:71) dalam penelitiannya tentang Pelaksanaan Program Alokasi Dana Desa Terhadap Peningkatan Kesejahteraan Masyarakat dalam Perspektif Ekonomi Islam memaparkan bahwa untuk mengetahui kesejahteraan masyarakat maka dapat digunakan beberapa tolak ukur yang meliputi tingkat pendapatan, pola konsumsi rumah tangga, pendidikan, kesehatan, dan perumahan. Adapun tolak ukur tersebut dapat dijelaskan sebagai berikut :
a. Tingkat Pendapatan
b. Pola Konsumsi Rumah Tangga
c. Pendidikan
d. Kesehatan
e. Perumahan

\subsection{Kerangka Pemikiran}

Kerangkan pemikiran dalam sebuah penelitian digunakan untuk mempermudah pemahaman secara teoritis mengenai variabel dan tolak ukur yang digunakan dalam penelitian, berikut kerangka pemikiran dari variabel bebas (independent variabel) yakni Pengaruh Alokasi Dana Desa (ADD) terhadap variabel terikat (dependent variabel) yakni Kesejahteraan Masyarakat Desa Air Hangat Kecamatan Air Hangat Timur Kabupaten Kerinci yang terdiri dari dua variabel, yaitu :

A. Variabel Bebas yang diberi tanda X (Alokasi Dana Desa)

Menurut Peraturan Bupati Kerinci Nomor 2 Tahun 2017 Tentang Tata Cara Pengalokasian, Penyaluran dan Penggunaan Alokasi Dana Desa, Bagi Hasil Pajak dan Retribusi Daerah pasal 2 ayat 2, dengan adanya pengaturan Tata Cara Pengalokasian ini dapat dijadikan sebagai acuan bagi Pemerintah Kecamatan dan Kabupaten dalam penyaluran dan pelaksanaan penggunaan Alokasi Dana Desa, Bagi Hasil Pajak dan Retribusi Daerah yang meliputi : 

a. Pembinaan
b. Pengawasan
c. Evaluasi

B. Variabel Terikat yang diberi tanda Y (Kesejahteraan Masyarakat)

Menurut Badan Pusat Statistik (BPS) dalam Wulandari (2017:71) dalam penelitiannya tentang Pelaksanaan Program Alokasi Dana Desa Terhadap Peningkatan Kesejahteraan Masyarakat dalam Perspektif Ekonomi Islam memaparkan bahwa untuk mengetahui kesejahteraan masyarakat maka dapat digunakan beberapa tolak ukur yang meliputi tingkat pendapatan, pola konsumsi rumah tangga, pendidikan, kesehatan, dan perumahan. Adapun tolak ukur tersebut dapat dijelaskan sebagai berikut :

a. Tingkat Pendapatan

b. Komposisi Pengeluaran Rumah Tangga

c. Pendidikan

d. Kesehatan

e. Perumahan

Kerangka pemikiran dari penelitian ini dapat digambarkan sebagai berikut

Gambar 1

Kerangka Pemikiran

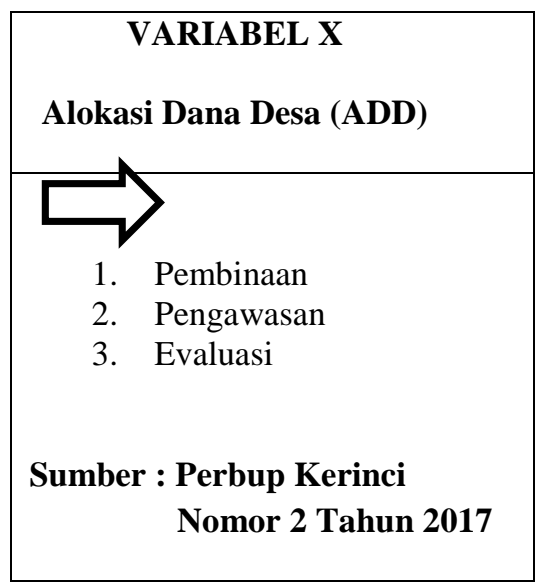

\begin{tabular}{|rl|}
\hline \multicolumn{1}{|c|}{ VARIABEL Y } \\
Kesejahteraan Masyarakat \\
\hline \\
1. & Tingkat Pendapatan \\
2. & Komposisi Pengeluaran \\
& $\quad$ Rumah Tangga \\
3. & Pendidikan \\
4. & Kesehatan \\
5. & Perumahan \\
& \\
Sumber : Wulandari (2017)
\end{tabular}




\subsection{Hipotesis}

Martono (2012:63) menyatakan bahwa "hipotesis adalah jawaban sementara yang kebenarannya masih harus diuji atau merupakan jawaban sementara atas pertanyaan penelitian". Dalam penelitian ini penulis merumuskan hipotesis yaitu diduga terdapat pengaruh yang signifikan antara Alokasi Dana Desa (ADD) Terhadap Kesejahteraan Masyarakat Desa Air Hangat Kecamatan Air Hangat Timur Kabupaten Kerinci. berikut :

Dari latar belakang diatas, dapat ditarik kesimpulan hipotesis sebagai

1. Ho $: r=0$ : Diduga tidak terdapat pengaruh yang signifikan antara Alokasi Dana Desa (ADD) Terhadap Kesejahteraan Masyarakat Desa Air Hangat Kecamatan Air Hangat Timur.

2. H1 $: r \neq 0$ : Diduga terdapat pengaruh yang signifikan Alokasi Dana Desa (ADD) Terhadap Kesejahteraan Masyarakat Desa Air Hangat Kecamatan Air Hangat Timur.

\section{Metode Penelitian}

Penelitian ini menggunakan pendekatan kuantitatif dengan motode survey menggunakan alat bantu kuisioner. Populasi dan sampel penelitian ini adalah seluruh Kepala Keluarga Desa Air Hangat dari RT 01 sampai dengan RT 06 dengan jumlah total $312 \mathrm{KK}$. Pengambilan sampel dalam penelitian ini dengan menggunakan teknik sampling sistematis yakni Kepala Keluarga RT 01 sampai dengan RT 06 diambil dengan nomor urut KK kelipatan 10 pada Data Penduduk Desa Air Hangat Tahun 2017 yang berjumlah 31 orang. Skala pengukuran yang digunakan adalah skala Likert, skala Likert digunakan mengukur hasil jawaban atau pendapat responden dengan lima pilihan jawaban yang memiliki tingkatan skor berbeda. Data yang akan diolah diperoleh melalui penyebaran angket kepada 31 orang kepala keluarga desa air hangat kecamatan air hangat timur kabupaten kerinci, yang kemudian dianalisis dengan mengunakan alat bantu program aplikasi computer SPSS Versi 16

\section{HASIL DAN PEMBAHASAN \\ 4.1 Hasil Uji Validitas}

Tabel 2

Hasil Uji Validitas Item Pernyataan Alokasi Dana Desa

\begin{tabular}{|c|c|c|c|}
\hline Item Pernyataan & r-hitung & r-tabel & Keterangan \\
\hline 1 & 0,744 & 0,355 & Valid \\
\hline 2 & 0,453 & 0,355 & Valid \\
\hline 3 & 0,472 & 0,355 & Valid \\
\hline 4 & 0,726 & 0,355 & Valid \\
\hline 5 & 0,471 & 0,355 & Valid \\
\hline 6 & 0,655 & 0,355 & Valid \\
\hline 7 & 0,709 & 0,355 & Valid \\
\hline 8 & 0,571 & 0,355 & Valid \\
\hline 9 & 0,468 & 0,355 & Valid \\
\hline 10 & 0,625 & 0,355 & Valid \\
\hline 11 & 0,726 & 0,355 & Valid \\
\hline 12 & 0,468 & 0,355 & Valid \\
\hline
\end{tabular}


Sumber : Data diolah

\begin{tabular}{|c|c|c|c|}
\hline 13 & 0,699 & 0,355 & Valid \\
\hline 14 & 0,694 & 0,355 & Valid \\
\hline 15 & 0,515 & 0,355 & Valid \\
\hline
\end{tabular}

Tabel 3

Hasil Uji Vaiditas Item Pernyataan Kesejahteraan Masyarakat

Sumber : Data diolah

\begin{tabular}{|c|c|c|c|}
\hline Item Pernyataan & r-hitung & r-tabel & Keterangan \\
\hline 1 & 0,703 & 0,355 & Valid \\
\hline 2 & 0,449 & 0,355 & Valid \\
\hline 3 & 0,462 & 0,355 & Valid \\
\hline 4 & 0,693 & 0,355 & Valid \\
\hline 5 & 0,480 & 0,355 & Valid \\
\hline 6 & 0,645 & 0,355 & Valid \\
\hline 7 & 0,704 & 0,355 & Valid \\
\hline 8 & 0,554 & 0,355 & Valid \\
\hline 9 & 0,466 & 0,355 & Valid \\
\hline 10 & 0,623 & 0,355 & Valid \\
\hline 11 & 0,701 & 0,355 & Valid \\
\hline 12 & 0,470 & 0,355 & Valid \\
\hline 13 & 0,659 & 0,355 & Valid \\
\hline 14 & 0,675 & 0,355 & Valid \\
\hline 15 & 0,505 & 0,355 & Valid \\
\hline
\end{tabular}

Tabel 2 dan 3 diatas merupakan hasil pengolahan data yang menunjukkan tingkat kevalidan atau kesahihan setiap item pertanyaan. Dari tabel diatas dapat dijelaskan bahwa seluruh item pernyataan untuk indikator Alokasi Dana Desa dan Kesejahteraan Masyarakat adalah valid. Dengan demikian seluruh item pertanyaan dalam penelitian ini dapat digunakan. Hal itu dibuktikan dengan nilai r-hitung lebih besar dari r-tabel.

\subsection{Uji Reliabilitas}

Tabel 4

Hasil Uji Reliabilitas Item Pernyataan Alokasi Dana Desa

\begin{tabular}{|c|c|c|c|}
\hline $\begin{array}{c}\text { Item } \\
\text { Pernyataan }\end{array}$ & $\begin{array}{c}\text { Cronbach's Alpha } \\
\text { if Item Delete }\end{array}$ & $\begin{array}{c}\mathbf{r} \text { - } \\
\text { tabel }\end{array}$ & Keterangan \\
\hline 1 & 0,862 & 0,355 & Reliabel \\
\hline 2 & 0,876 & 0,355 & Reliabel \\
\hline 3 & 0,876 & 0,355 & Reliabel \\
\hline 4 & 0,863 & 0,355 & Reliabel \\
\hline 5 & 0,875 & 0,355 & Reliabel \\
\hline 6 & 0,867 & 0,355 & Reliabel \\
\hline 7 & 0,864 & 0,355 & Reliabel \\
\hline 8 & 0,871 & 0,355 & Reliabel \\
\hline 9 & 0,875 & 0,355 & Reliabel \\
\hline 10 & 0,869 & 0,355 & Reliabel \\
\hline 11 & 0,873 & 0,355 & Reliabel \\
\hline 12 & 0,876 & 0,355 & Reliabel \\
\hline 13 & 0,865 & 0,355 & Reliabel \\
\hline 14 & 0,865 & 0,355 & Reliabel \\
\hline 15 & 0,873 & 0,355 & Reliabel \\
\hline
\end{tabular}

Sumber : Data diolah 
Tabel 5

Hasil Uji Reliabilitas Item Pernyataan Kesejahteraan Masyarakat

\begin{tabular}{|c|c|c|c|}
\hline $\begin{array}{c}\text { Item } \\
\text { Pernyataan }\end{array}$ & $\begin{array}{c}\text { Cronbach's Alpha if } \\
\text { Item Delete }\end{array}$ & $\begin{array}{c}\mathbf{r} \text { - } \\
\text { tabel }\end{array}$ & Keterangan \\
\hline 1 & 0,853 & 0,355 & Reliabel \\
\hline 2 & 0,865 & 0,355 & Reliabel \\
\hline 3 & 0,865 & 0,355 & Reliabel \\
\hline 4 & 0,853 & 0,355 & Reliabel \\
\hline 5 & 0,864 & 0,355 & Reliabel \\
\hline 6 & 0,856 & 0,355 & Reliabel \\
\hline 7 & 0,853 & 0,355 & Reliabel \\
\hline 8 & 0,861 & 0,355 & Reliabel \\
\hline 9 & 0,864 & 0,355 & Reliabel \\
\hline 10 & 0,857 & 0,355 & Reliabel \\
\hline 11 & 0,853 & 0,355 & Reliabel \\
\hline 12 & 0,865 & 0,355 & Reliabel \\
\hline 13 & 0,855 & 0,355 & Reliabel \\
\hline 14 & 0,855 & 0,355 & Reliabel \\
\hline 15 & 0,863 & 0,355 & Reliabel \\
\hline
\end{tabular}

Sumber : Data diolah

Tabel 4 dan 5 diatas merupakan hasil pengolahan data yang menunjukkan tingkat relibel setiap item pertanyaan. Dari tabel diatas dapat dijelaskan bahwa seluruh item pernyataan untuk indikator Alokasi Dana Desa dan Kesejahteraan Masyarakat adalah reliabel. Dengan demikian seluruh item pertanyaan dalam penelitian ini dapat digunakan. Hal itu dibuktikan dari nilai Corrected Item-Total Correlation lebih besar dari 0,355.

\subsection{Pengaruh Alokasi Dana Desa (ADD) Terhadap Kesejahteraan Masyarakat Desa Air Hangat Kecamatan Air Hangat Timur Kabupaten Kerinci}

Untuk mengetahui pengaruh Alokasi Dana Desa (ADD) terhadap kesejahteraan masyarakat Desa Air Hangat Kecamatan Air Hangat Timur Kabupaten Kerinci yaitu dengan persamaan Analisis Regresi Sederhana dengan variabel bebas Alokasi Dana Desa (X) dan variabel terikat Kesejahteraan Masyarakat (Y), adapun pengaruh dari variabel $\mathrm{X}$ terhadap variabel $Y$ dapat digambarkan dengan persamaan regresi sebagai berikut :

$\mathrm{Y}=38,803+0,401 \mathrm{X}$ dengan penjelasan nilai $\mathrm{a}=38,803$ adalah nilai konstanta artinya ketika variabel Alokasi Dana Desa dianggap konstan atau tidak ada perubahan, maka besarnya variabel Kesejahteraan Masyarakat akan naik sebesar 38,803 \%. Nilai $b=+0,401$ adalah nilai koefisien regresi dari variabel Alokasi Dana Desa. Tanda positif mengartikan bahwa terjadi peningkatan dari kesejahteraan masyarakat, jika Alokasi Dana Desa dinaikkan 100\% maka kesejahteraan masyarakat akan meningkat 40,1\%.

Dari penjelasan diatas dapat ditarik kesimpulan bahwa apabila Alokasi Dana Desa tidak mengalami perubahan atau konstan maka kesejahteraan masyarakat Desa Air Hangat Kecamatan Air Hangat Timur Kabupaten Kerinci akan naik sebesar 38,803. Kemudian apabila Alokasi Dana Desa dinaikkan 100\% maka kesejahteraan masyarakat Desa Air Hangat Kecamatan Air Hangat Timur Kabupaten Kerinci juga akan meningkat sebesar 40,1\%. Hal ini menunjukkan bahwa Alokasi Dana Desa mempengaruhi kesejahteraan masyarakat di Desa Air Hangat Kecamatan Air Hangat Timur Kabupaten Kerinci.

\subsection{Koefisien Determinasi}

Koefisien determinasi pada analisis regresi linear sederhana diartikan sebagai seberapa besar kemampuan variabel bebas dapat menjelaskan varian dari variabel 
terikatnya atau dengan kata lain koefisien determinasi merupakan hasil pengolahan data yang digunakan untuk mengetahui seberapa besar pengaruh dari variabel X (Alokasi Dana Desa) terhadap variabel Y (Kesejahteraan Masyarakat) di Desa Air Hangat Kecamatan Air Hangat Timur Kabupaten Kerinci, hasil dari analisis regresi linear sederhana yang menjelaskan seberapa besar pengaruh variabel $X$ terhadap varibel $Y$. Berdasarkan hasil analisisp R Square (determinasi) sebesar 0,153 (adalah pengkuadratan dari koefisien korelasi 0,391). Artinya 15,3\% kontribusi variabel Alokasi Dana Desa berpengaruh terhadap Kesejahteraan Masyarakat Desa Air Hangat. Sedangkan sisanya sebesar 84,7\% dipengaruhi oleh variabel lain yang tidak diteliti.

Dari penjelasan diatas dapat ditarik kesimpulan bahwa pengaruh Alokasi Dana Desa terhadap kesejahteraan masyarakat Desa Air Hangat Kecamatan Air Hangat Timur Kabupaten Kerinci ialah sebesar 15,3\%. Sedangkan sisanya yang mempengaruhi kesejahteraan masyarakat di Desa Air Hangat Kecamatan Air Hangat Timur Kabupaten Kerinci sebesar $84,7 \%$ dipengaruhi oleh sebab-sebab lain yang tidak diteliti dalam penelitian ini.

\subsection{Uji t}

Untuk mengetahui atau menguji signifikasi pengaruh variabel bebas (Independent) Alokasi Dana Desa dan variabel terikat (Dependent) Kesejahteraan Masyarakat Desa Air Hangat Kecamatan Air Hangat Timur Kabupaten Kerinci digunakan Uji Hipotesis $\mathrm{T}$ (Uji t). Untuk Signifikasi pengaruh Alokasi Dana Desa terhadap Kesejahteraan Masyarakat Desa Air Hangat Kecamatan Air Hangat Timur Kabupaten Kerinci maka dari uji coefficients atau uji $t_{\text {tes }}$ ternyata didapat $t_{\text {penelitian }} 2,287$ dengan tingkat signifikasi 0,030 . Untuk $t_{\text {tabel }}$ pada tingkat signifikasi 0,05 dan $D K=n-2$ atau 31-2 $=29$. Dari ketentuan tersebut diperoleh angka $t_{\text {tabel }}$ sebesar 2,045. Berdasarkan perhitungan diatas maka dapat diputuskan sebagai berikut : dimana $t_{\text {penelitian }}>t_{\text {tabel }}$ atau 2,287 $>2,045$ maka Ho ditolak dan $\mathrm{H} 1$ diterima, artinya terdapat pengaruh positif yang signifikan antara Alokasi Dana Desa terhadap Kesejahteraan Masyarakat Desa Air Hangat Kecamatan Air Hangat Timur Kabupaten Kerinci.

Dari penjelasan diatas dapat ditarik kesimpulan bahwa terdapat pengaruh positif yang signifikan antara variabel bebas (independent variabel) yakni Alokasi Dana Desa terhadap variabel terikat (independent variabel) yakni kesejahteraan masyarakat di Desa Air Hangat Kecamatan Air Hangat Timur Kabupaten Kerinci, hal tersebut dapat dibuktikan dengan hasil perolehan nilai $t_{\text {penelitian }}$ yakni 2,287 lebih besar dari nilai $t_{\text {tabel }}$ yakni 2,045.

\section{PENUTUP}

\subsection{Kesimpulan}

a. Apabila Alokasi Dana Desa tidak mengalami perubahan atau konstan maka kesejahteraan masyarakat Desa Air Hangat Kecamatan Air Hangat Timur Kabupaten Kerinci akan naik sebesar 38,803. Kemudian apabila Alokasi Dana Desa dinaikkan $100 \%$ maka kesejahteraan masyarakat Desa Air Hangat Kecamatan Air Hangat Timur Kabupaten Kerinci juga akan meningkat sebesar 40,1\%. Hal ini menunjukkan bahwa Alokasi Dana Desa mempengaruhi kesejahteraan masyarakat di Desa Air Hangat Kecamatan Air Hangat Timur Kabupaten Kerinci.

b. Pengaruh Alokasi Dana Desa terhadap kesejahteraan masyarakat Desa Air Hangat Kecamatan Air Hangat Timur Kabupaten Kerinci ialah sebesar 15,3\%. Sedangkan sisanya yang mempengaruhi kesejahteraan masyarakat di Desa Air Hangat Kecamatan Air Hangat Timur Kabupaten Kerinci sebesar 84,7\% dipengaruhi oleh sebab-sebab lain yang tidak diteliti dalam penelitian ini. 
c. Terdapat pengaruh positif yang signifikan antara Alokasi Dana Desa terhadap kesejahteraan masyarakat di Desa Air Hangat Kecamatan Air Hangat Timur Kabupaten Kerinci yang dibuktikan bahwa nilai $t_{\text {penelitian }}$ yakni 2,287 lebih besar dari nilai tabel yakni 2,045.

\subsection{Saran}

a. Pemerintah Desa Air Hangat selalu melakasanakan pembinaan tentang pelaksanaan ADD melalui pelatihan yang diikuti oleh Perangkat Desa sehingga pengelolaan ADD dapat terlaksana dengan baik dan tepat sasaran.

b. Pengawasan terhadap pelaksanaan ADD dilakukan sesuai prosedur seperti selalu melibatkan pihak-pihak yang mempunyai hak untuk mengawasi pelaksanaan ADD Kepala Desa, Masyarakat, BPD dan Instansi Berwenang serta pendamping Desa sehingga pelaksanaan ADD dapat berjalan dengan baik dan sesuai dengan tujuan yang telah ditetapkan sebelumnya.

c. Evaluasi yang dilakukan oleh Pemerintah Desa Air Hangat dalam pengelolaan ADD dilakukan secara rutin seperti melakukan evaluasi secara berkala untuk melihat sejauh mana pelaksanaan ADD telah tercapai dalam peningkatan kesejahteraan masyarakat.

d. Pemerintah Desa Air Hangat selalu memperhatikan mengenai pendidikan masyarakat seperti memantau anak-anak yang putus sekolah karena masalah ekonomi kemudian memberikan pengarahan tentang pentingnya pendidikan dan memberikan dukungan kepada mereka sehingga seluruh lapisan masyarakat dapat merasakan pendidikan secara baik dan merata.

e. Pemerintah Desa Air Hangat selalu memperhatikan layanan kesehatan yang diperoleh masyarakat seperti memperhatikan tentang tenaga kesehatan maupun sarana dan prasarana yang dibutuhkan dalam Desa sehingga dapat membantu seluruh lapisan masyarakat dalam mengakses layanan kesehatan dengan mudah. 


\section{DAFTAR PUSTAKA}

Arikunto, Suharsimi. 2010. Prosedur Penelitian Suatu Pendekatan Praktik. Jakarta : PT Rineka Cipta

Fahrudin, Adi. 2012. Pengantar Kesejahteraan Sosial. Bandung : Refika Aditama Martono, Nanang. 2010. Metode Penelitian Kuantitatif Analisis Isi dan Analisis Data Sekunder. Jakarta : PT. Raja Grafindo Persada

Natalia, Intan Indra. 2016. Kajian Tingkat Kesejahteraan dan Pendidikan Anak Petani Salak Pondoh di Desa Pekandangan Kecamatan Banjarmangu Kabupaten Banjarnegara. Skripsi. Universitas Muhammadiyah : Purwokerto.

Rosni. 2017. Analisis Tingkat Kesejahteraan Masyarakat Nelayan di Desa dahari Selebar Kecamatan Talawi Kabupaten Batubara. Jurnal Volume 9, No. 1.

Rusydi, Muhammad. 2012. Pengaruh Alokasi Dana Desa Terhadap

Kesejahteraan Masyarakat Desa di Kabupaten Takalar. Skripsi. Fakultas Ekonomi Unismuh : Makassar

Setiadi, Elly, M. 2006. Ilmu Sosial dan Budaya Dasar. Jakarta : Prenada Media Group

Sugiyono. 2009. Metode Penelitian Pendidikan Pendekatan Kuantitatif, Kualitatif, dan $R \& D$. Bandung : Alfabeta

Syekh, Sayid. 2011. Pengantar Statistik Ekonomi dan Sosial. Jakarta : Gaung Persada

Ujianto, Budi. Wuryanti, Nining. Abidin, Zaenal.2007. Sosiologi Untuk SMA/MA Kelas X. Depok : CV.Arya Duta

Undang-undang No. 6 Tahun 2014, Tentang Desa

Undang-undang No. 23, Tahun 20014, Tentang Pemerintahan Daerah

Peraturan Daerah Kabupaten Kerinci No. 5 Tahun 2007, Tentang Alokasi Dana Desa

Peraturan Bupati Kerinci No. 2 Tahun 2017, Tentang Tata Cara Pengalokasian, Penyaluran, Penggunaan, Alokasi Dana Desa, Bagi Hasil Pajak dan Retribusi Daerah. 